\title{
Effects of regulatory BCI RNA deletion on synaptic plasticity, learning, and memory
}

\author{
Ain Chung, ${ }^{1}$ Nessy Dahan, ${ }^{3}$ Juan Marcos Alarcon, ${ }^{2,3}$ and André A. Fenton ${ }^{1,2,4}$ \\ ${ }^{1}$ Center for Neural Science, New York University, New York, New York 10003, USA; ${ }^{2}$ The Robert F. Furchgott Center for Neural and \\ Behavioral Science, Brooklyn, New York 11203, USA; ${ }^{3}$ Department of Pathology; ${ }^{4}$ Department of Physiology and Pharmacology, State \\ University of New York Downstate Medical Center, Brooklyn, New York 11203, USA
}

\begin{abstract}
Nonprotein coding dendritic $\mathrm{BCl}$ RNA regulates translation of mRNAs in neurons. We examined two lines of $\mathrm{BCl}$ knockout mice and report that loss of $\mathrm{BCl}$ RNA exaggerates group I mGluR-stimulated LTD of the Schaffer collateral synapse, with one of the lines showing a much more enhanced DHPG-induced LTD than the other. When the animals were given the hippocampus-synaptic plasticity-dependent active place avoidance task, learning and memory were impaired in the $\mathrm{BCl}-\mathrm{KO}$ line with the more severely altered DHPG-induced LTD. These findings indicate a role for BCI RNA control of mGluR-dependent synaptic function in hippocampus and associated cognitive ability.
\end{abstract}

Brain cytoplasmic (BC) RNAs are a nonprotein-coding subtype of small cytoplasmic RNAs. BC1 RNA (BC200 in human and nonhuman primates) localizes to synapto-dendritic domains in neurons and regulates protein synthesis by targeting the initiation phase of translation (Tiedge et al. 1991, 1993; Wang et al. 2002, 2005; Eom et al. 2011, 2014). BC1 RNA may contribute to maintaining translation homeostasis at synapses because it (1) represses translation stimulated by group I metabotropic glutamate receptor (mGluR) activation, and (2) group I mGluR-stimulated translation of synaptic proteins is exaggerated in the absence of BC1 RNA (Wang et al. 2002; Lin et al. 2008; Eom et al. 2014). In contrast to the substantial knowledge of the molecular actions of small cytoplasmic RNAs, relatively little is known about the role of BC RNAs in neural function and behavior. Here, using BC1 knockout (KO) mice, we investigated whether absence of BC1 RNA alters hippocampus group 1 mGluR-stimulated synaptic plasticity and hippocampus-dependent cognitive behavior.

Two lines of $\mathrm{BC} 1 \mathrm{KO}$ mice were used; each derived from independent mutant ES cell lines. Each line initially had a mixed C57BL/6J and $129 \times 1 / \mathrm{SvJ}$ background (Skryabin et al. 2003). The first "BC1 KO-13" line still has the mixed C57BL/6J and 129×1/ SvJ background. The second, "BC1 KO-B" line, mostly has a C57BL/6J background, having been backcrossed over 15 generations. The corresponding WT-13 and WT-B wild-type (WT) mice were of the respective identical background. The mice were bred in house and were 8-12 wk old at the time of the physiological and behavioral assays. All procedures were carried out in accordance with the Public Health Service Policy on Humane Care and Use of Laboratory Animals and were approved by the SUNY, Downstate Medical Center and the New York University Institutional Animal Care and Use Committees.

To test whether the absence of BC1 RNA alters mGluRstimulated hippocampus synaptic function, we investigated mGluR-stimulated long-term depression DHPG-induced LTD of CA3-to-CA1 Schaffer collateral synapses (Huber et al. 2001). Ex vivo electrophysiology was performed as described (Alarcon et al. 2004; Nicholls et al. 2008). Right dorsal transverse hippocampal slices $(400 \mu \mathrm{m})$ were cut in ice-cold artificial cerebrospinal fluid (ACSF, in mM: $\mathrm{NaCl} 119, \mathrm{KCl} 4, \mathrm{MgSO}_{4} 1.5, \mathrm{CaCl}_{2} 2.5, \mathrm{NaHCO}_{3}$ 26.2, $\mathrm{NaH}_{2} \mathrm{PO}_{4}$ 1.0, and glucose 11 , saturated with $95 \% \mathrm{O}_{2}, 5 \%$

Corresponding author: afenton@nyu.edu

Article is online at http://www.learnmem.org/cgi/doi/10.1101//m.045617.117.
$\mathrm{CO}_{2}$ ). Slices recovered at $36^{\circ} \mathrm{C}$ for 45 and $60 \mathrm{~min}$ at room temperature in ACSF and were then set in an interface recording chamber perfused with ACSF at $36^{\circ} \mathrm{C}$. Field excitatory postsynaptic potentials (fEPSPs) from the CA1 "stratum radiatum" were evoked (pulse duration: $50 \mu$, pulse sampling: $0.017 \mathrm{~Hz}$, pulse intensity: 40\% of the maximum fEPSP slope) and detected using a pair of stimulation bipolar (FHC \& Co) and recording borosilicate glass pipette (5-10 $\mathrm{m} \Omega$ filled with ACSF; Sutter Instruments) electrodes. The group I mGluR agonist 3,5-dihydroxyphenylglycine (DHPG, 50 $\mu \mathrm{M}$; Sigma-Aldrich) was used to induce DHPG-induced LTD (Huber et al. 2001). fEPSP responses were acquired using PClamp (Molecular Devices) and analyzed using Origin (Microcal Software). ANOVA with repeated measures, followed by the Holm-Šídák test for multiple comparisons were performed using Prism (GraphPad Software).

Expression of DHPG-induced LTD was quantified as the reduction in fEPSP slope 40 min after DHPG treatment relative to the 15-min baseline prior to application of DHPG (Fig. 1). Because DHPG-induced LTD was indistinguishable for WT-13 mice and WT-B mice, they were combined into a single WT group. This was statistically justified because there were 5 mice per group and oneway ANOVA power analysis with three groups, $\alpha=0.05$ and $\beta=$ 0.95 , and the observed effect size $1.7\left(\eta^{2}=0.75\right)$, calls for group sizes of four. BC1 KO-B animals showed enhanced DHPG-induced LTD expression $(65.18 \pm 14.06 \%)$ compared with WT mice $(86.45 \pm$ $6.42 \%)$ and it was even larger in $\mathrm{BC} 1 \mathrm{KO}-13$ mice (40.64 \pm $10.20 \%)$. These observations were confirmed by a significant effect of genotype $\left(F_{(2,23)}=29.96 ; P<0.0001\right)$, and according to post hoc tests, the ranking of DHPG-induced LTD enhancement was BC1 KO-13 mice $>$ BC1 KO-B mice $>$ WT mice. These data indicate a role of BC1 RNA regulation of group I mGluR-dependent synaptic function, which is greater in $\mathrm{BC} 1 \mathrm{KO}-13$ mice than $\mathrm{BC} 1 \mathrm{KO}-\mathrm{B}$ mice.

Next we evaluated cognitive behavior in these two BC1 KO lines by testing them in the hippocampus synaptic plasticitydependent active place avoidance paradigm (Cimadevilla et al. 2001; Pastalkova et al. 2006; Park et al. 2015). The place avoidance system consisted of a circular (40-cm diameter) rotating $(1 \mathrm{rpm})$

\footnotetext{
(C) 2017 Chung et al. This article is distributed exclusively by Cold Spring Harbor Laboratory Press for the first 12 months after the full-issue publication date (see http://learnmem.cshlp.org/site/misc/terms.xhtml). After 12 months, it is available under a Creative Commons License (AttributionNonCommercial 4.0 International), as described at http://creativecommons. org/licenses/by-nc/4.0/.
} 
A

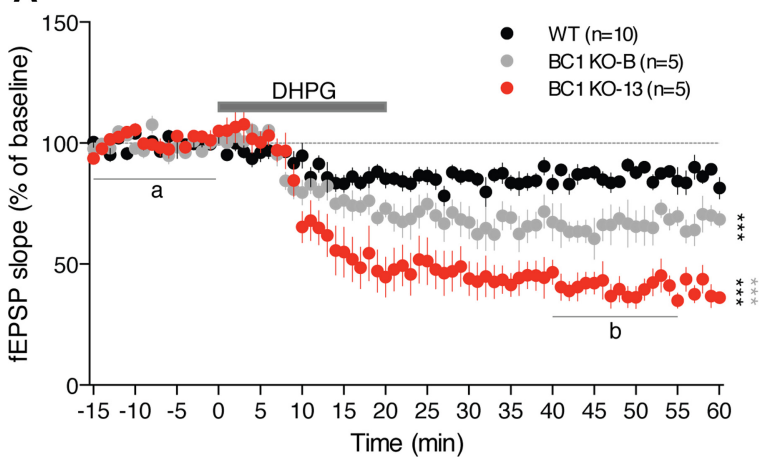

B

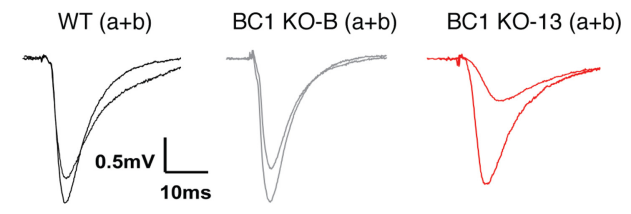

Figure 1. Absence of BC1 RNA exaggerates DHPG-induced LTD at the CA3-CA1 hippocampal synapse. (A) The graph shows the time course of CA3CA1 synaptic responses during baseline recordings, induction of LTD by DHPG (50 $\mu \mathrm{M}$ for $20 \mathrm{~min}$, solid gray line), and the washout period (40 min). DHPG-induced LTD is exaggerated in slices from BC1 KO-13 mice, in comparison with those from WT and BC1 KO-B mice. (B) Traces illustrate representative examples of evoked responses. At baseline, all groups showed similar fEPSP responses to the stimulation (a), but BC1 KO-13 animals showed the smallest slope of the fEPSP after DHPG application (b). Significant differences relative to WT mice at 40-55 min (for 15 min after 20 min of washout) are indicated by black asterisks, and relative to $\mathrm{BC} 1 \mathrm{KO}-\mathrm{B}$ mice by gray asterisks ( $\left.{ }^{\star * *}\right) P<0.0001$. $\mathrm{BC} 1 \mathrm{KO}-13, n=5 ; \mathrm{BC} 1 \mathrm{KO}-\mathrm{B}, n=5 ; \mathrm{WT}, n=10$.

arena located inside a behavioral room. PC-based video tracking (Tracker, Bio-Signal Group) triggered a constant current $(60 \mathrm{~Hz}$, $500 \mathrm{msec}, 0.2 \mathrm{~mA}$ ) footshock when the mouse entered a $60^{\circ}$ shock zone for more than $500 \mathrm{msec}$, as described in Radwan et al. (2016). The shock repeated every $1.5 \mathrm{sec}$ until the mouse exited the shock zone. Because the location of shock was fixed to the spatial cues that were placed around the room, effective place avoidance requires mice to use spatial information from the stationary distal room cues.

On the first day of the behavioral protocol, the mice were habituated to the rotating arena for 30 min without shock. On the second day, each mouse received three 30-min training sessions with $2 \mathrm{~h}$ between sessions. On the third day, 24-h long-term memory retention was tested in identical conditions. Two hours later, two conflict training sessions were given with the shock sector relocated $180^{\circ}$ from the original location, which was the preferred location during prior training. Indices of learning and memory were computed by TrackAnalysis software (Bio-Signal Group).

$\mathrm{BC} 1 \mathrm{KO}$ and $\mathrm{WT}$ animals explored the rotating arena similarly during the pretraining session in which the shock was off (Fig. 2A). Locomotion was similar, measured by the total distance moved $\left(F_{(2,17)}=0.68, P=0.5\right)$, consistent with prior reports of no hyperactivity in BC1 KO mice (Lewejohann et al. 2004).

Place avoidance training began the next day with activation of the shock zone. Across the three training trials, all genotypes decreased the number of times they entered the shock zone, indicating place learning (Fig. 2B). The two WT groups were indistinguishable and so were combined, as in the DHPG-induced LTD study. This was statistically justified because the group sizes were 5 or 6 mice and two-way ANOVA power analysis with three groups, $\alpha=0.05$ and $\beta=0.95$, and the observed interaction effect size $=0.60$ $\left(\eta^{2}=0.26\right)$ calls for group sizes of four. The BC1 KO-13 mice were slower to learn the avoidance in comparison to the BC1 KO-B mice and WT mice, which did not appear to differ from each other.

Indeed, the WT and $\mathrm{BC} 1 \mathrm{KO}-\mathrm{B}$ mice also showed the typical across-trial increase in how far they were able to walk before first entering the shock zone on each trial, indicating they formed longterm place memory, whereas the $\mathrm{BC} 1 \mathrm{KO}-13$ did not demonstrate a clear increase. Twenty-four hour memory retention also looked clearly impaired in $\mathrm{BC} 1 \mathrm{KO}-13$ mice, assessed by the path-to-firstentrance measure but a learning deficit was not expressed on this 24 -h retention trial. Relocating the shock zone for the conflict sessions initially caused all animals to increase the number of entries to the new shock zone, which they entered virtually immediately.
Because the $\mathrm{BC} 1 \mathrm{KO}-13$ mice were slowest to learn the initial shock zone and did not express strong memory retention, one might have expected them to have the least difficulty with the conflict, because their initial conditioned place response was presumably easier to suppress than the well-learned responses of the other groups. However, the $\mathrm{BC} 1 \mathrm{KO}-13$ seemed to be more disturbed than the WT and BC1 KO-B mice. The mice appeared to subsequently learn to avoid the new shock zone because the number of entrances decreased across the two conflict sessions in all the genotypes, but long-term memory was not expressed in BC1 KO-13 mice as their path to the first entrance did not appear to increase, indicating impaired cognitive flexibility. These impressions were confirmed by two-way genotype $\times$ trial ANOVAs, with repeated measures on the factor trial. The effects of genotype (entrances: $F_{(2,20)}=9.73, P<0.005$; path to first enter: $\left.F_{(2,20)}=3.55, P<0.05\right)$ and trial (entrances: $F_{(6,120)}=158.7, P<0.0001$; path to first enter: $\left.F_{(6,120)}=6.50, P<0.0001\right)$ were significant for both the measure of learning (Fig. 2B) and the measure of long-term memory retention (Fig. 2C). The interaction was significant for the number of entrances $\left(F_{(12,120)}=2.63, P<0.005\right)$ but not for the path to the first entrance $\left(F_{(12,120)}=1.26, P<0.25\right)$. Post hoc tests confirmed no differences between $\mathrm{WT}$ and $\mathrm{BC} 1 \mathrm{KO}-\mathrm{B}$ mice, and relative to these genotypes, the $\mathrm{BC} 1 \mathrm{KO}-13$ mice were impaired on the initial learning and conflict trials (Fig. 2B). The $\mathrm{BC} 1 \mathrm{KO}-13$ mice expressed impaired long-term memory relative to $\mathrm{WT}$ and $\mathrm{BC} 1 \mathrm{KO}-\mathrm{B}$ mice on the 24-h retention and the two conflict trials once long-term memory was strongly expressed by the other genotypes (Fig. 2C). BC1 KO-13 mice express cognitive impairments in active place avoidance not observed in $\mathrm{BC} 1 \mathrm{KO}-\mathrm{B}$ mice. While there is no evidence that DHPG-induced LTD abnormality causes the cognitive deficits, a larger abnormality in DHPG-induced LTD is observed in BC1 KO-13 mice, and we do not know what additional consequences the loss of BC1 RNA throughout the brain may have had (e.g., compensatory changes). The present findings demonstrate functional abnormality after loss of BC1 RNA by demonstrating, for the first time, synaptic plasticity changes and parallel impairment of behavior known to involve the altered synapses.

Prior behavioral work contrasts with the present findings. In that work, BC1-mutant mice expressed impaired spontaneous exploratory behavior and higher anxiety-like behavior but no differences in learning or memory assessed by a test battery that included the Barnes, Water, Radial 8-Arm, Multiple-T, and alley mazes (Lewejohann et al. 2004). The task variant we used is no more stressful than exploration of a familiar space (Lesburgueres 
A
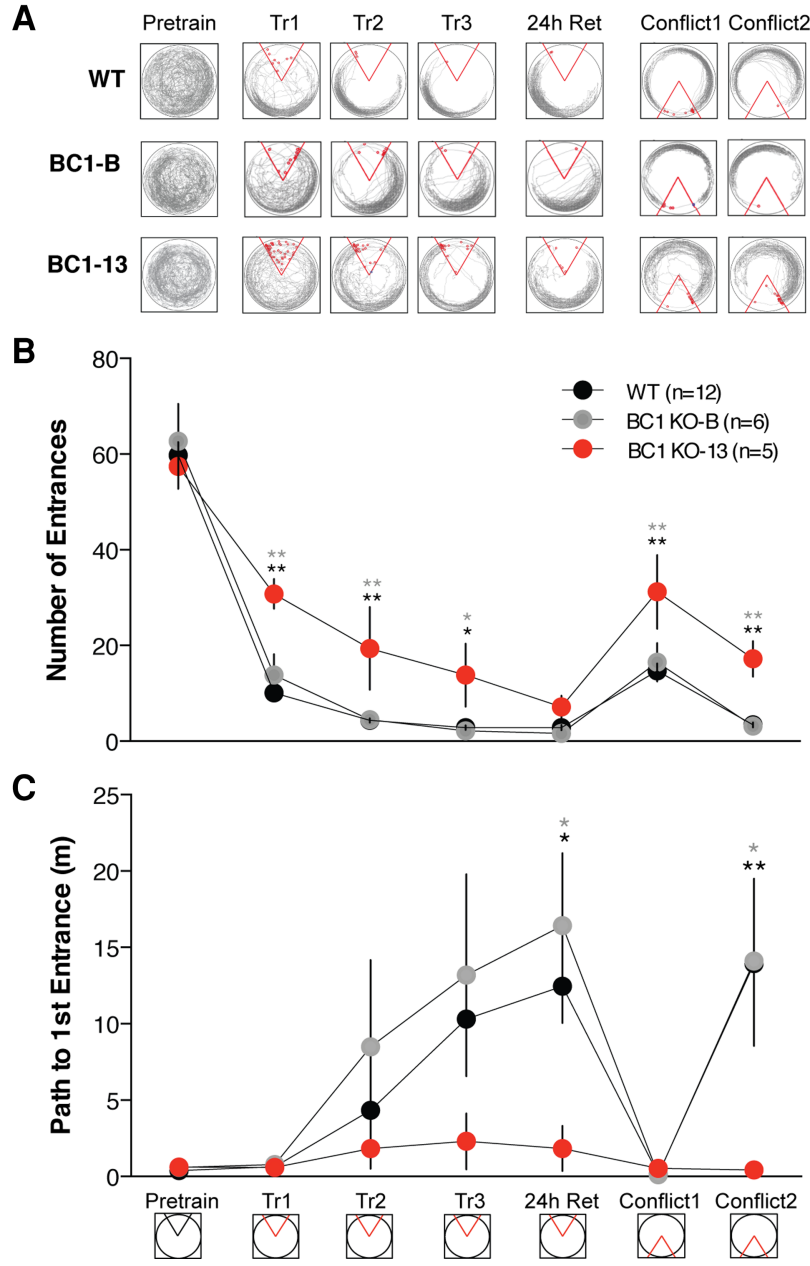

Figure 2. Impaired spatial learning, memory, and cognitive flexibility in BC1 KO-13 animals in the active place avoidance task. (A) The panels show the tracking of a representative mouse for each group across the pretraining, training, 24-h retention test, and conflict training sessions. (B) BC1 KO-13 mice entered the shock zone (red sector in A) more often than BC1 KO-B or WT mice during the initial and conflict training sessions, suggesting a deficit in learning during training to avoid the initial shock zone location as well as during conflict training trials. (C) BC1 KO-13 mice were also impaired relative to the other two genotypes in the 24-h memory retention test, which was assessed by a shorter path walked before entering the shock zone for the first time. Significant differences relative to WT mice are indicated by black asterisks, and relative to $\mathrm{BC} 1 \mathrm{KO}-\mathrm{B}$ mice by gray asterisks $\left(^{*}\right) P<$ $\left.0.05,{ }^{* *}\right) P<0.005, \mathrm{BC} 1 \mathrm{KO}-13, n=5 ; \mathrm{BC} 1 \mathrm{KO}-\mathrm{B}, n=6 ; \mathrm{WT}, n=12$.

et al. 2017), and it is sensitive to inactivation of the basolateral amygdala, orbitofrontal, and retrosplenial cortices (Vafaei and Rashidy-Pour 2004; Vafaei et al. 2007; Wesierska et al. 2009). It may be one of the most sensitive tasks to dorsal hippocampal dysfunction because it is even impaired by unilateral hippocampal inactivation (Cimadevilla et al. 2001). Not only does the task require place learning and persistent hippocampus LTP-dependent memory persistence (Pastalkova et al. 2006; Park et al. 2015; Tsokas et al. 2016; Hsieh et al. 2017; Pavlowsky et al. 2017), but distinct from water maze place learning (Kubík and Fenton 2005), the active place avoidance task also requires cognitive control to segregate and prioritize information about stable locations over information about rotating locations (Bures et al. 1997; Wesierska et al. 2005; Kelemen and Fenton 2010). This cognitive control component may have been critical to detecting the deficits because impaired cognitive control, assessed in an odor discrimination attentional set-shifting task was also recently reported in these $\mathrm{BC} 1 \mathrm{KO}$ strains (Iacoangeli et al. 2017).

Absence of BC1 RNA resulted in exaggerated DHPG-induced LTD. This follows because dendritically transported BC1 RNA interacts with the translation initiation machinery by binding to eukaryotic initiation factors eIF4A (an RNA helicase) and eIF4B (a modulator of eIF4A function), thereby blocking the recruitment and formation of $48 \mathrm{~S}$ initiation complexes (Wang et al. 2002; Lin et al. 2008; Eom et al. 2014). While we did not experimentally block translation in the present studies, anisomycin was used in prior investigations of BC1-mutant mice that confirmed $\mathrm{BC} 1$ RNA represses translation downstream from MEK-ERK signaling in a sequential-independent manner to the fragile $\mathrm{X}$ mental retardation protein (FMRP) (Zhong et al. 2010). Consequently, BC1 RNA absence results in hippocampal CA3 hyperexcitability following group I mGluR stimulation and audiogenic seizures, both of which are blocked by pretreatment with anisomycin (Zhong et al. 2009), and are further exaggerated when FMRP is also absent (Zhong et al. 2010). While it is beyond the present scope to determine whether other forms of synaptic function and plasticity are also altered, diverse abnormalities are predicted given the broad expression of $\mathrm{BC} 1 \mathrm{RNA}$ and its role in repressing translation.

The present findings add to prior reports of increased synthesis of synaptic proteins (Cheng et al. 1996), increased prolonged CA3 epileptiform discharges, increased susceptibility to audiogenic seizures, and excessive cortical $\gamma$ oscillations in the absence of BC1 RNA, all of which are triggered by group 1 mGluR stimulation (Zhong et al. 2009, 2010; Iacoangeli and Tiedge 2013). Given that BC1 RNA and FMRP both repress translation, albeit by different mechanisms, it is noteworthy that all of these abnormalities have also been observed in Fmr1 KO mice that lack FMRP to model the FXS genetic defect (Huber et al. 2001; Chuang et al. 2005; Zhong et al. 2010; Bhakar et al. 2012; Gonçalves et al. 2013; Radwan et al. 2016). Causal relationships remain to be confirmed among these abnormalities that span the molecular, cellular, network, and behavioral levels of biological organization.

The two BC1 KO strains differed in the severity of the abnormalities that we measured. Prior work with the BC1 KO-B mice showed a mild active place avoidance deficit (Zhong et al. 2010), using a harder to learn protocol of three 10-min sessions per day for $3 \mathrm{~d}$ (Tsokas et al. 2016), however, the deficit was not as severe as we observed in the $\mathrm{BC} 1 \mathrm{KO}-13$ strain. It is well documented that both physiology and behavior can be impacted by the background strain of a mouse (Yoshiki and Moriwaki 2006; Spencer et al. 2011; Darnell 2014; Ishimura et al. 2014; Lei et al. 2014). Phenotypic differences including fear-learning deficits due to Fmr1 deletion are weaker in C57Bl/6 mice compared with the $129 \times 1 /$ SvJ strain (Paradee et al. 1999; Moy et al. 2009; Spencer et al. 2011). The strain differences we observed could arise because BC1 RNA translational control is extraordinary in the C57Bl/6J strain compared with other strains (Darnell 2014; Ishimura et al. 2014), and thus less severe phenotypic consequences of BC1 RNA absence could manifest in the BC1 KO-B line. Known complex molecular interactions may also play a role. Specifically, BC1 RNA binds to FMRP to increase the protein's mRNA target specificity (Zalfa et al. 2003). In addition, FMRP expression is higher in the absence of BC1 RNA, measured with both background strains (Zhong et al. 2009). Thus the differences we detected in the phenotypic expression of the two $\mathrm{BC} 1 \mathrm{KO}$ strains highlight the potential importance of genetic background. In the present case, there is both the possibility of background-strain dependent partial compensation for loss of BC1-mediated translation repression by FMRP as well as exaggerated FMRP loss of function in the absence of BC1 RNA (Zalfa et al. 2003; Zhong et al. 2009). In addition, the differences may also result from the nonlinear relationships between deficits in molecular signaling, physiological, and 
behavioral consequences, a fact that presents a major challenge to understanding how molecular mechanisms of disease and dysfunction cause clinical symptoms (Mitchell et al. 2013). The present findings add to the evidence that translation regulation in neurons, including by nonprotein coding RNA, is a mechanism of complex neural circuit and brain function, the disruption of which is sufficient to result in synaptic plasticity and cognitive dysfunction (Darnell et al. 2011).

\section{Acknowledgments}

We thank Henri Tiedge for providing mice. This work was supported in part by National Institutes of Health (NIH) grants NS081625 and NS091830 (J.M.A), MH099128 (A.A.F.)

\section{References}

Alarcon JM, Hodgman R, Theis M, Huang YS, Kandel ER, Richter JD. 2004 Selective modulation of some forms of schaffer collateral-CA1 synaptic plasticity in mice with a disruption of the CPEB-1 gene. Learn Mem 11: 318-327.

Bhakar AL, Dölen G, Bear MF. 2012. The pathophysiology of fragile X (and what it teaches us about synapses). Annu Rev Neurosci 35: 417-443.

Bures J, Fenton AA, Kaminsky Y, Rossier J, Sacchetti B, Zinyuk L. 1997. Dissociation of exteroceptive and idiothetic orientation cues: effect on hippocampal place cells and place navigation. Philos Trans R Soc Lond B Biol Sci 352: 1515-1524.

Cheng JG, Tiedge H, Brosius J. 1996. Identification and characterization of BC1 RNP particles. DNA Cell Biol 15: 549-559.

Chuang SC, Zhao W, Bauchwitz R, Yan Q, Bianchi R, Wong RK. 2005. Prolonged epileptiform discharges induced by altered group I metabotropic glutamate receptor-mediated synaptic responses in hippocampal slices of a fragile X mouse model. J Neurosci 25: 8048-8055.

Cimadevilla JM, Wesierska M, Fenton AA, Bures J. 2001. Inactivating one hippocampus impairs avoidance of a stable room-defined place during dissociation of arena cues from room cues by rotation of the arena. Proc Natl Acad Sci 98: 3531-3536.

Darnell JC. 2014. Molecular biology. Ribosome rescue and neurodegeneration. Science 345: 378-379.

Darnell JC, Van Driesche SJ, Zhang C, Hung KY, Mele A, Fraser CE, Stone EF, Chen C, Fak JJ, Chi SW, et al. 2011. FMRP stalls ribosomal translocation on mRNAs linked to synaptic function and autism. Cell 146: 247-261.

Eom T, Berardi V, Zhong J, Risuleo G, Tiedge H. 2011. Dual nature of translational control by regulatory BC RNAs. Mol Cell Biol 31: 4538-4549.

Eom T, Muslimov IA, Tsokas P, Berardi V, Zhong J, Sacktor TC, Tiedge H. 2014. Neuronal BC RNAs cooperate with eIF4B to mediate activity-dependent translational control. J Cell Biol 207: 237-252.

Gonçalves JT, Anstey JE, Golshani P, Portera-Cailliau C. 2013. Circuit level defects in the developing neocortex of Fragile X mice. Nat Neurosci 16: 903-909.

Hsieh C, Tsokas P, Serrano P, Hernández AI, Tian D, Cottrell JE, Shouval HZ, Fenton AA, Sacktor TC. 2017. Persistent increased PKM $\zeta$ in long-term and remote spatial memory. Neurobiol Learn Mem 138: 135-144.

Huber KM, Roder JC, Bear MF. 2001. Chemical induction of mGluR5- and protein synthesis-dependent long-term depression in hippocampal area CA1. J Neurophysiol 86: 321-325.

Iacoangeli A, Tiedge H. 2013. Translational control at the synapse: role of RNA regulators. Trends Biochem Sci 38: 47-55.

Iacoangeli A, Dosunmu A, Taesun E, Stefanov DG, Tiedge H. 2017. Regulatory BC1 RNA in Cognitive Control. Learn Mem 24: 267-277.

Ishimura R, Nagy G, Dotu I, Zhou H, Yang XL, Schimmel P, Senju S, Nishimura Y, Chuang JH, Ackerman SL. 2014. RNA function. Ribosome stalling induced by mutation of a CNS-specific tRNA causes neurodegeneration. Science 345: 455-459.

Kelemen E, Fenton AA. 2010. Dynamic grouping of hippocampal neural activity during cognitive control of two spatial frames. PLOS Biol 8 : e1000403.

Kubík S, Fenton AA. 2005. Behavioral evidence that segregation and representation are dissociable hippocampal functions. J Neurosci 25: 9205-9212.

Lei P, Ayton S, Moon S, Zhang Q, Volitakis I, Finkelstein DI, Bush AI. 2014. Motor and cognitive deficits in aged tau knockout mice in two background strains. Mol Neurodegener 9: 29.

Lesburgueres E, Sparks FT, O'Reilly KC, Fenton AA. 2016. Active place avoidance is no more stressful than unreinforced exploration of a familiar environment. Hippocampus 26: 1481-1485.

Lewejohann L, Skryabin BV, Sachser N, Prehn C, Heiduschka P, Thanos S, Jordan U, Dell'Omo G, Vyssotski AL, Pleskacheva MG, et al. 2004. Role of a neuronal small non-messenger RNA: behavioural alterations in BC1 RNA-deleted mice. Behav Brain Res 154: 273-289.

Lin D, Pestova TV, Hellen CU, Tiedge H. 2008. Translational control by a small RNA: dendritic BC1 RNA targets the eukaryotic initiation factor 4A helicase mechanism. Mol Cell Biol 28: 3008-3019.

Mitchell KJ, O'Donnell P, Durstewitz D, Fenton AA, Gingrich JA, Gordon JA, Kelsch W, Moghaddam B, Phillips WA, Sawa A. 2013. A framework for the use of models in schizophrenia. In Schizophrenia: evolution and synthesis, (ed. Silverstein SM, Moghaddam B, Wykes T), pp. 212-226. MIT Press, Cambridge, MA.

Moy SS, Nadler JJ, Young NB, Nonneman RJ, Grossman AW, Murphy DL, D'Ercole AJ, Crawley JN, Magnuson TR, Lauder JM. 2009. Social approach in genetically engineered mouse lines relevant to autism. Genes Brain Behav 8: 129-142.

Nicholls RE, Alarcon JM, Malleret G, Carroll RC, Grody M, Vronskaya S, Kandel ER. 2008. Transgenic mice lacking NMDAR-dependent LTD exhibit deficits in behavioral flexibility. Neuron 58: 104-117.

Paradee W, Melikian HE, Rasmussen DL, Kenneson A, Conn PJ, Warren ST. 1999. Fragile X mouse: strain effects of knockout phenotype and evidence suggesting deficient amygdala function. Neuroscience 94: 185-192.

Park EH, Burghardt NS, Dvorak D, Hen R, Fenton AA. 2015. Experience-dependent regulation of dentate gyrus excitability by adult-born granule cells. J Neurosci 35: 11656-11666.

Pastalkova E, Serrano P, Pinkhasova D, Wallace E, Fenton AA, Sacktor TC. 2006. Storage of spatial information by the maintenance mechanism of LTP. Science 313: 1141-1144.

Pavlowsky A, Wallace E, Fenton AA, Alarcon JM. 2017. Persistent modifications of hippocampal synaptic function during remote spatial memory. Neurobiol Learn Mem 138: 182-197.

Radwan B, Dvorak D, Fenton A. 2016. Impaired cognitive discrimination and discoordination of coupled $\theta-\gamma$ oscillations in Fmr1 knockout mice. Neurobiol Dis 88: 125-138.

Skryabin BV, Sukonina V, Jordan U, Lewejohann L, Sachser N, Muslimov I, Tiedge H, Brosius J. 2003. Neuronal untranslated BC1 RNA: targeted gene elimination in mice. Mol Cell Biol 23: 6435-6441.

Spencer CM, Alekseyenko O, Hamilton SM, Thomas AM, Serysheva E, Yuva-Paylor LA, Paylor R. 2011. Modifying behavioral phenotypes in Fmr1KO mice: genetic background differences reveal autistic-like responses. Autism Res 4: 40-56.

Tiedge H, Fremeau RT Jr, Weinstock PH, Arancio O, Brosius J. 1991. Dendritic location of neural BC1 RNA. Proc Natl Acad Sci 88: 2093-2097.

Tiedge H, Zhou A, Thorn NA, Brosius J. 1993. Transport of BC1 RNA in hypothalamo-neurohypophyseal axons. J Neurosci 13: 4214-4219.

Tsokas P, Hsieh C, Yao Y, Lesburguères E, Wallace EJ, Tcherepanov A Jothianandan D, Hartley BR, Pan L, Rivard B, et al. 2016. Compensation for $\mathrm{PKM} \zeta$ in long-term potentiation and spatial long-term memory in mutant mice. Elife 5: e14846.

Vafaei AA, Rashidy-Pour A. 2004. Reversible lesion of the rat's orbitofrontal cortex interferes with hippocampus-dependent spatial memory. Behav Brain Res 149: 61-68.

Vafaei AA, Jezek K, Bures J, Fenton AA, Rashidy-Pour A. 2007. Post-training reversible inactivation of the rat's basolateral amygdala interferes with hippocampus-dependent place avoidance memory in a time-dependent manner. Neurobiol Learn Mem 88: 87-93.

Wang H, Iacoangeli A, Popp S, Muslimov IA, Imataka H, Sonenberg N, Lomakin IB, Tiedge H. 2002. Dendritic BC1 RNA: functional role in regulation of translation initiation. J Neurosci 22: 10232-10241.

Wang H, Iacoangeli A, Lin D, Williams K, Denman RB, Hellen CU, Tiedge H. 2005. Dendritic BC1 RNA in translational control mechanisms. J Cell Biol 171: 811-821.

Wesierska M, Dockery C, Fenton AA. 2005. Beyond memory, navigation, and inhibition: behavioral evidence for hippocampus-dependent cognitive coordination in the rat. J Neurosci 25: 2413-2419.

Wesierska M, Adamska I, Malinowska M. 2009. Retrosplenial cortex lesion affected segregation of spatial information in place avoidance task in the rat. Neurobiol Learn Mem 91: 41-49.

Yoshiki A, Moriwaki K. 2006. Mouse phenome research: implications of genetic background. ILAR J 47: 94-102.

Zalfa F, Giorgi M, Primerano B, Moro A, Di Penta A, Reis S, Oostra B, Bagni C. 2003. The fragile $X$ syndrome protein FMRP associates with BC1 RNA and regulates the translation of specific mRNAs at synapses. Cell 112: 317-327.

Zhong J, Chuang SC, Bianchi R, Zhao W, Lee H, Fenton AA, Wong RK, Tiedge H. 2009. BC1 regulation of metabotropic glutamate receptor-mediated neuronal excitability. I Neurosci 29: 9977-9986.

Zhong J, Chuang SC, Bianchi R, Zhao W, Paul G, Thakkar P, Liu D, Fenton AA, Wong RK, Tiedge H. 2010. Regulatory BC1 RNA and the fragile $\mathrm{X}$ mental retardation protein: convergent functionality in brain. PLoS One 5: e15509.

Received March 17, 2017; accepted in revised form August 17, 2017. 


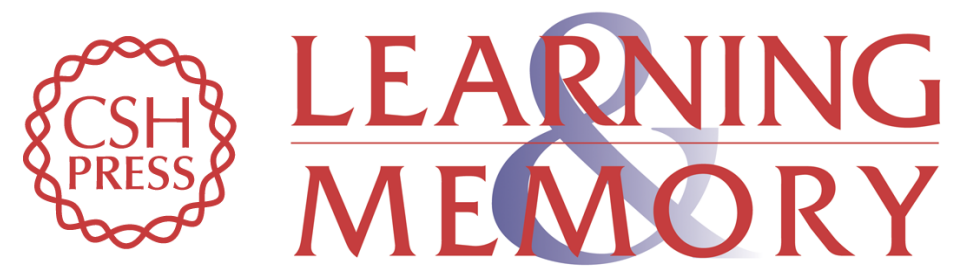

\section{Effects of regulatory BC1 RNA deletion on synaptic plasticity, learning, and memory}

Ain Chung, Nessy Dahan, Juan Marcos Alarcon, et al.

Learn. Mem. 2017, 24:

Access the most recent version at doi:10.1101/lm.045617.117

References This article cites 44 articles, 19 of which can be accessed free at: http://learnmem.cshlp.org/content/24/12/646.full.html\#ref-list-1

Creative This article is distributed exclusively by Cold Spring Harbor Laboratory Press for the Commons License first 12 months after the full-issue publication date (see

http://learnmem.cshlp.org/site/misc/terms.xhtml). After 12 months, it is available under a Creative Commons License (Attribution-NonCommercial 4.0 International), as described at http://creativecommons.org/licenses/by-nc/4.0/.

Email Alerting Receive free email alerts when new articles cite this article - sign up in the box at the Service top right corner of the article or click here. 